\title{
Studi Karakteristik Campuran AC-BC Berdasarkan Limbah Kantong Plastik Sebagai Bahan Tambah
}

\author{
Sri Yuniarti ${ }^{\star 1}$, Rais Rachman ${ }^{\star 2}$, Alpius ${ }^{\star 3}$ \\ *1 Mahasiswa Program Studi Teknik Sipil, Universitas Kristen Indonesia Paulus, Makassar, Indonesia \\ sriyuniartits@gmail.com \\ *2,3 Dosen Program Studi Teknik Sipil, Universitas Kristen Indonesia Paulus, Makassar, Indonesia \\ rais.rachman@gmail.com dan alpiusnini@gmail.com
}

\begin{abstract}
ABSTRAK
Penelitian ini dimaksudkan untuk studi karakteristik campuran AC-BC berdasarkan limbah kantong plastik sebagai bahan tambah. Pencampuran dilakukan dengan menambahkan potongan plastik pada campuran aspal berdasarkan cara kering. Metode dalam penelitian ini adalah melakukan serangkaian pengujian karakteristik agregat kasar, halus, dan filler kemudian merancang komposisi campuran AC-BC serta pengujian Marshall untuk mendapatkan karakteristik campuran dan pengujian Marshall Immersion untuk memperoleh indeks kekuatan sisa (IKS). Melalui uji Marshall, kadar limbah kantong plastik yang digunakan yaitu $0 \%, 0,5 \%, 1 \%, 1,5 \%$, dan $2 \%$. Hasil penelitian yang dilakukan di laboratorium Jalan dan Aspal Fakultas Teknik Jurusan Sipil Universitas Kristen Indonesia Paulus Makassar, menunjukkan bahwa penggunaan bahan tambah (Additive) pada campuran aspal beton lapis antara dapat meningkatkan nilai stabilitas. Nilai stabilitas akibat penambahan plastik pada campuran aspal meningkat dibandingkan campuran aspal tanpa plastik. Kadar penambahan plastik yang baik untuk campuran aspal yaitu $2 \%$ karena selain nilai stabilitasnya tinggi, parameter Marshall seperti VIM, Flow, VMA, dan VFB juga telah memenuhi syarat Spesifikasi Direktorat Jendral Bina Marga 2018.
\end{abstract}

Kata Kunci : Karakteristik, AC-BC, Limbah Plastik

\begin{abstract}
This research is intended to study the characteristics of a mixture of AC-BC using plastic bag waste as added material. Mixing is done by adding pieces of plastic to the asphalt mixture using a dry method. The method in this research is to conduct a series of testing the characteristics of coarse, fine, and filler aggregates then design the AC-BC mixture composition and Marshall testing to obtain mixture characteristics and Marshall Immersion testing to obtain the residual strength index (IKS). Through the Marshall test, the level of plastic bag waste used is $0 \%, 0.5 \%, 1 \%, 1.5 \%$, and $2 \%$. The results of research conducted at the Road and Asphalt Laboratory of the Faculty of Civil Engineering, Indonesian Christian University, Paulus Makassar, showed that the use of additives in intermediate asphalt concrete mixtures can increase stability values. The stability value due to the addition of plastic to the asphalt mixture increases compared to asphalt mixture without plastic. The level of good addition of plastic to asphalt mix is $2 \%$ because in addition to the high stability value, Marshall parameters such as VIM, Flow, VMA, and VFB have also fulfilled the 2018 Directorate General of Highways Specifications.
\end{abstract}

Keywords: Characteristics, AC-BC, Plastic Waste

\section{PENDAHULUAN}

Perkerasan jalan merupakan hal utama untuk menunjang keamanan dan kenyamanan dalam bertransportasi. Perkerasan jalan harus mempunyai daya dukung dan keawetan yang memadai, tetapi juga memiliki nilai yang ekonomis. Namun, dalam pemanfaatannya perkerasan jalan banyak mengalami gangguan atau kerusakan yang disebabkan oleh beberapa faktor diantaranya mutu atau kualitas jalan yang tidak sesuai dengan klasifikasi jalan sehingga menyebabkan kinerja perkerasan jalan menurun dan umur jalan menjadi lebih singkat. Untuk mencegah terjadinya kerusakan pada permukaan perkerasan jalan, bisa ditambahkan bahan pengikat dapat berupa campuran agregat dan bahan tambahan lainnya untuk meningkatkan stabilitas dan durabilitas aspal tersebut.

Limbah yang berupa plastik sangat sering kita jumpai dalam kehidupan sehari-hari. Plastik juga memiliki kelebihan antara lain ringan, kuat, dan tahan terhadap korosi. Sejalan dengan Indonesia yang menduduki peringkat kedua penghasil limbah plastik dan meningkatnya Indonesia dalam bidang infrastruktur terutama di bidang jalan, peran plastik dapat dibutuhkan dalam hal ini. 
Pada penelitian digunakan plastik (kantong plastik) dengan mutu rendah yang memiliki karakteristik tingkat resistensi kimia yang sangat baik. Plastik bersifat termoplastik, memiliki densitas antara $0.910-0.940 \mathrm{~g} / \mathrm{cm} 3$, tidak reaktif pada temperatur suhu kamar, kecuali oleh oksidator kuat dan beberapa jenis pelarut dapat menyebabkan kerusakan. Memiliki percabangan yang banyak sehingga gaya antar molekulnya rendah.

Lapis aspal beton adalah suatu lapisan pada konstuksi jalan raya, yang terdiri dari agregat menerus dengan aspal keras, dicampur, dihamparkan dan dipadatkan pada suhu tertentu [1]. Lapisan aspal beton (laston) juga banyak digunakan sebagai lapis permukaan jalan yang melayani lalu lintas sedang. Campuran beraspal Laston terdiri dari 3 (tiga) macam, Laston Lapis Aus (AC-WC), Laston Lapis Pengikat (AC-BC), Laston Lapis Fondasi (AC-Base). Pada penelitian ini berdasarkan Laston Lapis Pengikat (AC-BC) [2].

Untuk mengetahui karakteristik campuran, menentukan ketahanan atau stabilitas terhadap kelelehan plastis (flow) dari campuran aspal, maka dilakukan pengujian dengan berdasarkan alat Marshall [3]. Pengujian ini berdasarkan 3 buah benda uji untuk setiap kadar aspal yang digunakan [4]. Parameter Pengujian Marshall adalah Stabilitas, Flow, Voids in Mixture (VIM), Void in Mineral Aggregate (VMA), Void Filled with Bitumen (VFB), Marshall Quotient (MQ), Indeks Kekuatan Sisa (IKS) [5].

Peneliti yang pernah melakukan penelitian tentang penggunaan bahan limbah untuk campuran laston antara lain, Tandibua at.al (2020) meneliti tentang durabilitas dan permeabilitas Laston $\mathrm{BC}$ dengan sabut kelapa sebagai bahan subtitusi filler [6]. Datu at.al. (2020) meneliti tentang pengaruh penambahan limbah kelapa sawit terhadap permeabilitas campuran laston AC-WC [7]. Bunga at.al. (2019) meneliti tentang pengaruh variasi tumbukan terhadap indeks kekuatan sisa pada campuran AC- WC [8]. Sumardi at.al (2019) mengkaji pemanfaatan ampas tebu sebagai pengganti filler pada campuran Aspal beton [9]. Angga at.al meneliti tentang karakteristik campuran AC-WC dan AC-BC berdasarkan bahan tambah serat ijuk [10].

Tujuan penelitian adalah Menganalisis komposisi campuran AC-BC yang berdasarkan limbah kantong plastik sebagai bahan tambah dan mengidentifikasi nilai parameter Marshall sebagai karakteristik fisik beton aspal.

\section{METODOLOGI PENELITIAN}

\section{Tahapan penelitian}

Tahapan penelitian yang dilakukan di laboratorium dapat dilihat pada Gambar 1 berikut:

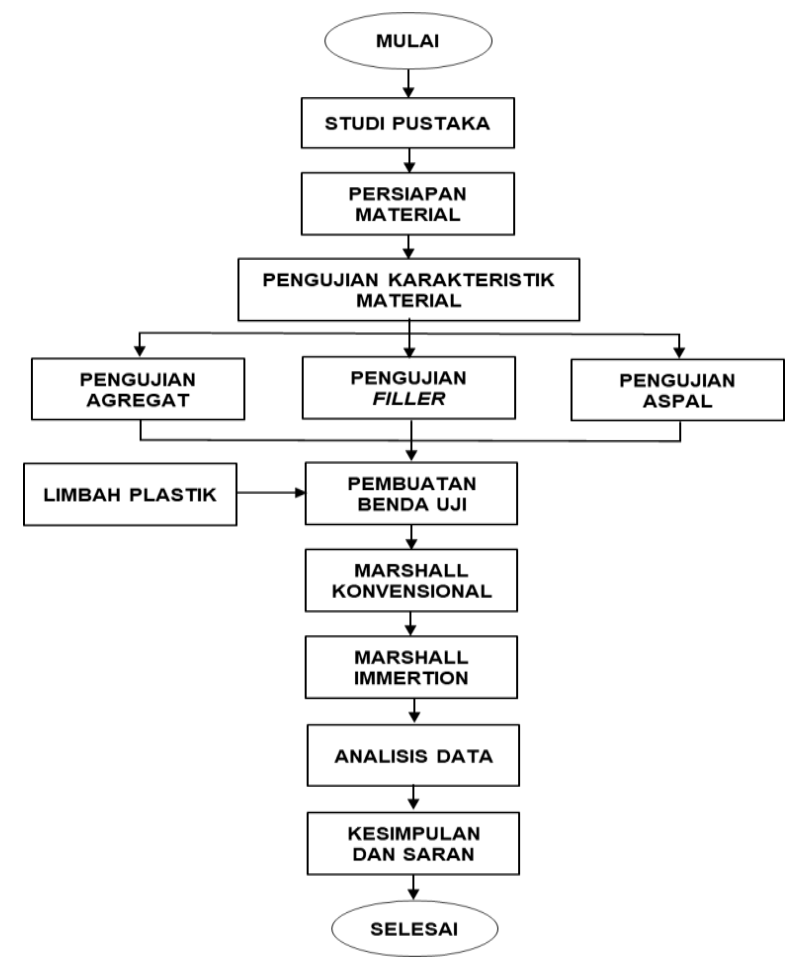

Gambar 1. Bagan Alir Penelitian

\section{Pengambilan dan Persiapan Bahan}

Kegiatan pengujian sifat bahan dimaksudkan untuk mengetahui karakteristik dari setiap bahan uji, apakah bahan tersebut mempunyai karakteristik yang memenuhi spesifikasi untuk digunakan. Melakukan persiapan bahan (material) yaang akan diteliti di laboratorium jalan dan aspal UKI Paulus Makassar merupakan hal awal yang harus dilakukan dalam pelaksanaan penelitian

\section{Bahan Tambahan Limbah Kantong Plastik}

Untuk persyaratan limbah kantong plastik yang digunakan sebagai bahan tambah adalah kantong plastik berwarna hitam ukuran $17 \mathrm{~cm} \times 33 \mathrm{~cm}$ yang telah dicuci, dicacah dan dalam keadaan kering agar menghindari bahan organik yang akan mencemari campuran beraspal. Umumnya kantong plastik ini berbentuk utuh sehingga untuk mencampurkannya dengan aspal harus di cacah terlebih dahulu. Karena penggunaan kantong plastik pada penelitian ini tidaklah banyak, maka pencacahan dilakukan dengan alat manual (digunting) dengan ukuran $1 \mathrm{~cm}$. Penambahan limbah kantong plastik untuk menaikkan mutu campuran beraspal ada dua cara, yaitu cara basah (wet process) dimana plastic ditambahkan kedalam aspal panas dan dicampur hingga homogen. Dan cara kedua yaitu cara kering (dry process) dimana plastik ditambahkan kedalam agregat panas. 


\section{Pengujian Karakteristik Bahan}

a. Pengujian agregat

- Analisa Saringan berdasarkan SNI ASTM C136 : 2012.

- Pengujian Abrasi dengan mesin Los Angeles berdasarkan SNI 2417:2008.

- Pengujian Kelekatan Agregat terhadap Aspal berdasarkan SNI 2439:2011.

- Pemeriksaan Berat Jenis (Bulk) berdasarkan SNI 03-1969-2008 dan penyerapan Agregat berdasarkan SNI 031969-2008.

- Pemeriksaan Kadar Lumpur/Sand Equivalent Test berdasarkan SNI 03-44281997.

- Pemeriksaan Partikel Pipih dan Lonjong mengunakan ASTM D-4791 Perbandingan 1:10.

- Pengujian Material Lolos Ayakan No.200 (kasar dan halus) yang Lolos Saringan Nomor 200/0,075 mm mengunakan SNI ASTM 117-2012.

b. Pengujian Karakteristik Aspal

- Pengujian Daktilitas pada suhu $25^{\circ} \mathrm{C}$ berdasarkan SNI 2432:2011.

- Pengujian Titik Lembek $\left({ }^{\circ} \mathrm{C}\right)$ berdasarkan SNI 2434:2011.

- Pengujian Titik Nyala $\left({ }^{\circ} \mathrm{C}\right)$ berdasarkan SNI 2433:2011.

- Pengujian Berat Jenis berdasarkan SNI 2441:2011.

- Pengujian Berat yang Hilang (\%) berdasarkan SNI 06-2441-1991.

- Pengujian Penetrasi pada suhu $25^{\circ} \mathrm{C}$ berdasarkan SNI 06-2456-2011.

c. Pengujian Berat Jenis Filler

Pengujian Berat Jenis Filler berdasarkan standar rujukan SNI ASTM C 136:2012.

\section{Proporsi Campuran}

Proporsi campuran AC-BC yang digunakan adalah campuran aspal panas (Hot mix) yang terdiri dari komponen-komponen agregat yang merupakan komponen terbesar dalam campuran dengan berdasarkan variasi penambahan limbah kantong plastik sebesar $0 \%, 0,5 \%, 1 \%, 1,5 \%$, dan $2 \%$ dari berat total aspal. Proporsi campuran dapat dilihat pada tabel 1 .

Tabel 1. Proporsi campuran

\begin{tabular}{lccccc}
\hline \multirow{2}{*}{\multicolumn{1}{c}{ Material }} & \multicolumn{5}{c}{ Kadar campuran } \\
\cline { 2 - 6 } & $0 \%$ & $0,50 \%$ & $1,00 \%$ & $1,50 \%$ & $2,00 \%$ \\
\hline Berat Agregat kasar (gr) & 511,68 & 511,68 & 511,68 & 511,68 & 511,68 \\
Berat Agregat halus (gr) & 545,40 & 545,40 & 545,40 & 545,40 & 545,40 \\
Berat Filler semen(gr) & 64,92 & 64,92 & 64,92 & 64,92 & 64,92 \\
Berat aspal (gr) & 78,00 & 77,61 & 77,22 & 76,83 & 76,44 \\
Limbah plastik (gr) & 0,00 & 0,39 & 0,78 & 1,17 & 1,56 \\
\hline Berat campuran (gr) & 1200,00 & 1200,00 & 1200,00 & 1200,00 & 1200,00 \\
\hline
\end{tabular}

\section{ANALISIS DAN PEMBAHASAN}

Data dan Analisis Campuran Beraspal

1. Karakteristik Agregat dan Filler

Hasil pengujian agregat kasar maupun pengujian agregat halus serta Filler memenuhi standar SNI yang dipersyaratkan. Hasil pengujian dapat dilihat pada tabel 2 dan pengujian Analisa saringan dapat dilihat ada gambar 2 .

Tabel 2. Hasil pengujian agregat

\begin{tabular}{|c|c|c|c|}
\hline No. & Pengujian & Persyaratan & $\begin{array}{c}\text { Hasil } \\
\text { Pengujian }\end{array}$ \\
\hline \multirow[t]{5}{*}{1} & Abrasi dengan mesin Los Angeles & \multirow{5}{*}{$\operatorname{Max} 40 \%$} & \\
\hline & Fraksi A & & $4,96 \%$ \\
\hline & Fraksi B & & $4,48 \%$ \\
\hline & Fraksi C & & $4,20 \%$ \\
\hline & Fraksi D & & $4,90 \%$ \\
\hline 2 & Kelekatan Agregat terhadap Aspal & Min. 95\% & $>98 \%$ \\
\hline \multirow[t]{5}{*}{3} & \multicolumn{3}{|c|}{ Jenis dan penyerapan air aggergat kasar } \\
\hline & - Bulk & Min. $2,5 \%$ & $2,64 \%$ \\
\hline & - SSD & Min. $2,5 \%$ & $2,69 \%$ \\
\hline & - Apparent & Min. $2,5 \%$ & $2,77 \%$ \\
\hline & - Penyerapan & $\operatorname{Max} 3 \%$ & $1,86 \%$ \\
\hline \multirow[t]{5}{*}{4} & \multicolumn{3}{|c|}{ Berat Jenis dan penyerapan air aggergat halus } \\
\hline & - Bulk & Min. $2,5 \%$ & $2,58 \%$ \\
\hline & - SSD & Min. $2,5 \%$ & $2,61 \%$ \\
\hline & - Apparent & Min. $2,5 \%$ & $2,66 \%$ \\
\hline & - Penyerapan & $\operatorname{Max} 3 \%$ & $1,11 \%$ \\
\hline \multirow[t]{3}{*}{5} & Pemeriksaan Kadar Agregat halus & & \\
\hline & - Sand Equivalent & $\min .50 \%$ & $96,26 \%$ \\
\hline & - Kadar lumpur & Makx. $5 \%$ & $3,74 \%$ \\
\hline \multirow[t]{5}{*}{6} & Partikel pipih & & \\
\hline & - 3/4" & \multirow{4}{*}{ Max. $10 \%$} & $7,97 \%$ \\
\hline & - 1/2" & & $8,99 \%$ \\
\hline & $-3 / 8 "$ & & $4,81 \%$ \\
\hline & $-1 / 4 "$ & & - \\
\hline \multirow[t]{5}{*}{7} & Partikel Lonjong & \multirow{5}{*}{ Max. $10 \%$} & \\
\hline & - 3/4" & & $8,68 \%$ \\
\hline & - 1/2" & & $9,77 \%$ \\
\hline & $-3 / 8 "$ & & $7,89 \%$ \\
\hline & $-1 / 4^{\prime \prime}$ & & - \\
\hline 8 & Material Lolos Ayakan No.200 & Max. $10 \%$ & $8 \%$ \\
\hline 9 & Berat Jenis Filler & -- & 3,09 \\
\hline
\end{tabular}

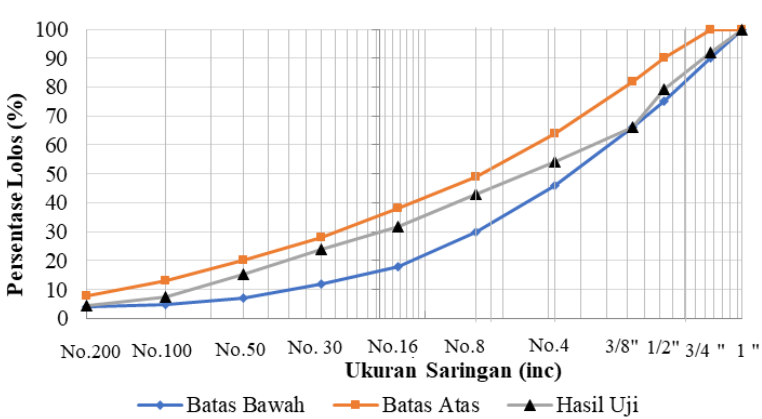

Gambar 2. Hasil pengujian Analisa saringan

\section{Karakteristik Aspal}

Hasil pengujian aspal semua memenuhi persyaratan sebagai bahan campuran AC-WC. Hasil pengujian dapat dilihat pada tabel 3 . 
Tabel 3. Hasil pengujian aspal

\begin{tabular}{clcc}
\hline No. & \multicolumn{1}{c}{ Pengujian } & Persyaratan & $\begin{array}{c}\text { Hasil } \\
\text { Pengujian }\end{array}$ \\
\hline 1 & Daktilitas pada suhu $25^{\circ} \mathrm{C}$ & Min. $100 \mathrm{~cm}$ & $150 \mathrm{~cm}$ \\
2 & Titik Lembek $\left({ }^{\circ} \mathrm{C}\right)$ & $48-58{ }^{\circ} \mathrm{C}$ & $51,5^{\circ} \mathrm{C}$ \\
3 & Titik Nyala dan titik bakar $\left({ }^{\circ} \mathrm{C}\right)$ & Min. $232^{\circ} \mathrm{C}$ & $290^{\circ} \mathrm{C}$ \\
4 & Berat Jenis & Min. $1 \mathrm{gr} / \mathrm{cc}$ & $1,051 \mathrm{gr} / \mathrm{cc}$ \\
5 & Berat yang Hilang $(\%)$ & Max. $0,8 \%$ & $0,35 \%$ \\
6 & Penetrasi pada suhu $25^{\circ} \mathrm{C}$ & $60-70 \mathrm{~mm}$ & 67 \\
7 & Penetrasi pada TFOT & Min. $54 \%$ & $83,60 \%$ \\
\hline
\end{tabular}

\section{Marshall Konvensional}

Untuk menganalisis data penelitian pada marshall konvensional maka sebelumnya harus diketahui nilai pengujian bulk (berat jenis) dari masingmasing agregat yang dipakai pada penelitian ini. Untuk nilai yang biperoleh dapat dilihat pada tabel 2.

\section{a. Voids in Mixture (VIM)}

Nilai VIM hasil analisis dapat dilihat pada pada tabel 4. Dari nilai tersebut dibuatkan grafik dan didapatkan persamaan gari seperti pada gambar 3 .

Tabel 4. Nilai VIM

\begin{tabular}{cccccc}
\hline $\begin{array}{c}\text { Kadar Plastik } \\
(\%)\end{array}$ & 0.00 & 0.50 & 1.00 & 1.50 & 2.00 \\
\hline \multirow{2}{*}{ VIM } & 3.60 & 3.42 & 3.31 & 3.24 & 3.21 \\
& 3.56 & 3.46 & 3.39 & 3.28 & 3.14 \\
& 3.51 & 3.50 & 3.35 & 3.26 & 3.12 \\
Rata-Rata & 3.55 & 3.46 & 3.35 & 3.26 & 3.16 \\
\hline Persyaratan & & & $3-5 \%$ \\
\hline
\end{tabular}

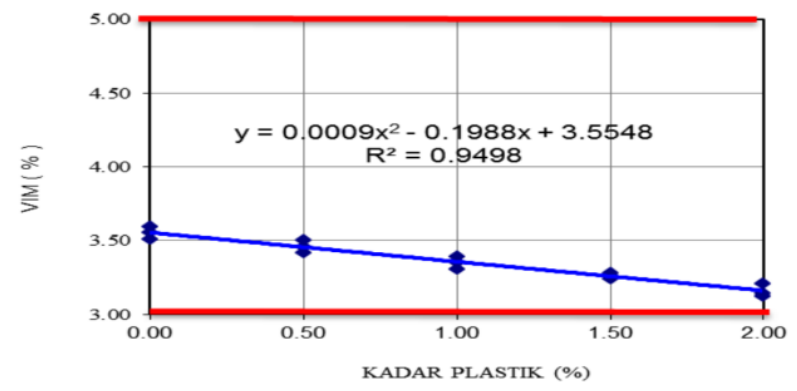

Gambar 4. Hubungan VIM Dengan Kadar Plastik

Dari gambar 4 dapat diketahui untuk subtitusi kadar plastik $0 \%$ - $2 \%$ diperoleh nilai VIM antara $3,16-3,55$. Nilai VIM dengan kadar plastik $0 \%$, $0,5 \%, 1 \%, 1,5 \%$ dan $2 \%$ memenuhi persyaratan. Dari gambar 4 juga diketahui bahwa semakin tinggi kadar plastik yang digunakan maka nilai VIM akan semakin kecil (berkurang) karena kadar plastik yang tinggi akan mengisi rongga-rongga dalam campuran sehingga rongga yang tidak terisi aspal (VIM) semakin berkurang. b. Stabilitas

Nilai stabilitas hasil pengujian disajikan pada tabel 5 dari nilai tersebut dibuatkan trend garis stabilitas sepert pada gambar 5 .

Tabel 5. Nilai Stabilitas

\begin{tabular}{cccccc}
\hline $\begin{array}{c}\text { Kadar Plastik } \\
(\%)\end{array}$ & 0.00 & 0.50 & 1.00 & 1.50 & 2.00 \\
\hline \multirow{3}{*}{ Stabilitas } & 1331.56 & 1331.56 & 1424.05 & 1546.81 & 1571.37 \\
& 1343.55 & 1343.55 & 1399.50 & 1534.54 & 1559.09 \\
& 1319.56 & 1319.56 & 1436.33 & 1559.09 & 1583.64 \\
\hline Rata-Rata & 1331.56 & 1331.56 & 1419.96 & 1546.81 & 1571.37 \\
\hline Persyaratan & \multicolumn{5}{c}{ Min $800 \mathrm{~kg}$} \\
\hline
\end{tabular}

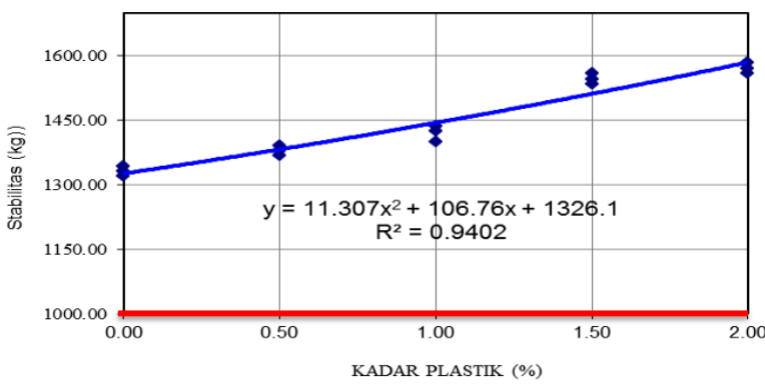

Gambar 5. Hubungan Stabilitas Dengan Kadar Pastik

Dengan menggunakan kadar plastik $0 \%-2 \%$ diperoleh nilai Stabilitas antara 1331.56 - 1571.37. Dengan demikian nilai Stabilitas dengan kadar plastik $0 \%, 0,5 \%, 1 \%, 1,5 \%$, dan $2 \%$. Berdasarkan Gambar 5 dapat disimpulkan bahwa Stabilitas tertinggi terdapat pada kadar plastik $2 \%$ yaitu 1571.37. Stabilitas berbanding lurus dengan persentasi bahan tambah hal ini diakibatkan oleh variasi limbah kantong plastik yang dicampur dengan aspal, dengan demikian pada penelitian ini semakin banyak kadar limbah plastik yang digunakan maka nilai stabilitas semakin besar. Hal ini terjadi karena limbah plastik juga mampu mengisi ruang dan mengikat agregat dengan aspal sehingga ikatan semakin tinggi.

\section{c. VMA (Void in Mineral Aggregate)}

Nilai VMA dari hasil analisis dapat dilihat pada tabel 6. Dari nilai pada tabel tersebut dibuat trend garis seperti pada gambar 6 .

\section{Tabel 6. Nilai Void in Mineral Aggregate}

\begin{tabular}{cccccc}
\hline $\begin{array}{c}\text { Kadar Plastik } \\
(\%)\end{array}$ & 0.00 & 0.50 & 1.00 & 1.50 & 2.00 \\
\hline \multirow{2}{*}{ VMA } & 17.36 & 17.20 & 17.11 & 17.05 & 17.02 \\
& 17.32 & 17.24 & 17.18 & 17.09 & 16.97 \\
& 17.28 & 17.27 & 17.15 & 17.07 & 16.95 \\
\hline Rata-rata & 17.32 & 17.24 & 17.15 & 17.07 & 16.98 \\
\hline Persyaratan & \multicolumn{5}{c}{ Min 14\% } \\
\hline
\end{tabular}

Dengan menggunakan kadar plastik 0\% - 2\% diperoleh nilai VMA antara 16,98 - 17,32. Nilai VMA dengan kadar plastik $0 \%, 0,5 \%, 1 \%, 1,5 \%$ dan $2 \%$. 
Berdasarkan Gambar 6, maka dapat diperoleh bahwa semakin besar kadar plastik maka nilai VMA akan kecil, dikarenakan semakin berkurangnya volume rongga yang terdapat didalam butir agregat karena aspal yang ada di dalam campuran selain menyelimuti agregat, juga akan masuk mengisi rongga dalam agregat tersebut.

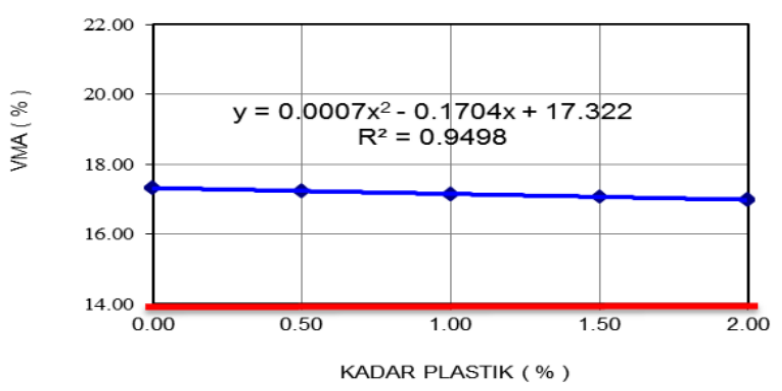

Gambar 6. Hubungan VMA Dengan Kadar Plastik

\section{d. Flow}

Nilai hasil pengujian flow seperti pada tabel 7. Dari nilai tersebut dibuatkan trend garis seperti pada gambar 7.

Tabel 7. Nilai hasil pengujian flow

\begin{tabular}{cccccc}
\hline $\begin{array}{c}\text { Kadar Plastik } \\
(\%)\end{array}$ & 0.00 & 0.50 & 1.00 & 1.50 & 2.00 \\
\hline \multirow{3}{*}{ Flow } & 2.40 & 2.40 & 2.35 & 2.30 & 2.20 \\
& 2.41 & 2.35 & 2.32 & 2.28 & 2.23 \\
& 2.45 & 2.37 & 2.31 & 2.26 & 2.21 \\
\hline Rata-rata & 2.42 & 2.37 & 2.33 & 2.28 & 2.21 \\
\hline Persyaratan & \multicolumn{5}{c}{$2-4(\mathrm{~mm})$} \\
\hline
\end{tabular}

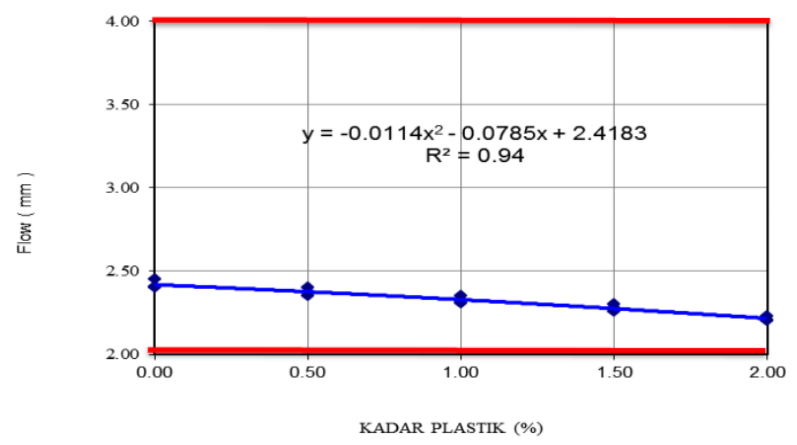

Gambar 7. Hubungan Flow Dengan Kadar Plastik

Dengan menggunakan kadar plastik $0 \%-2 \%$ diperoleh nilai Flow antara 3,21 - 2.42. Nilai Flow dengan kadar plastik $0 \%, 0,5 \%, 1 \%, 1,5 \%$ dan $2 \%$ Berdasarkan Gambar 7 dapat disimpulkan bahwa semakin banyak kadar limbah plastik yang digunakan maka nilai flow akan semakin kecil hubungan antara variasi kadar limbah plastik dengan flow dapat disimpulkan bahwa semakin besar kadar plastik maka nilai flow akan semakin kecil. Hal ini terjadi karena limbah plastik meleleh ketika berada pada suhu tinggi sehingga ketika dipadatkan limbah plastik menjadi cepat mengeras dan kaku. Hal ini mengakibatkan turunnya nilai kelenturan.

\section{e. VFB (Void Filled With Bitumen)}

Hasil analisis VFB dapat dilihat pada tabel 8. dari tabel tersebut trend garis didapatkan seperti pada gambar 8.

Tabel 8. Nilai VFB

\begin{tabular}{cccccc}
\hline $\begin{array}{c}\text { Kadar Plastik } \\
(\%)\end{array}$ & 0.00 & 0.50 & 1.00 & 1.50 & 2.00 \\
\hline & 79.28 & 80.14 & 80.66 & 80.98 & 81.16 \\
VFB & 79.47 & 79.95 & 80.25 & 80.79 & 81.47 \\
& 79.68 & 79.74 & 80.45 & 80.88 & 81.57 \\
\hline Rata-rata & 79.48 & 79.94 & 80.45 & 80.88 & 81.40 \\
\hline Persyaratan & \multicolumn{5}{c}{ Min 65\% } \\
\hline
\end{tabular}

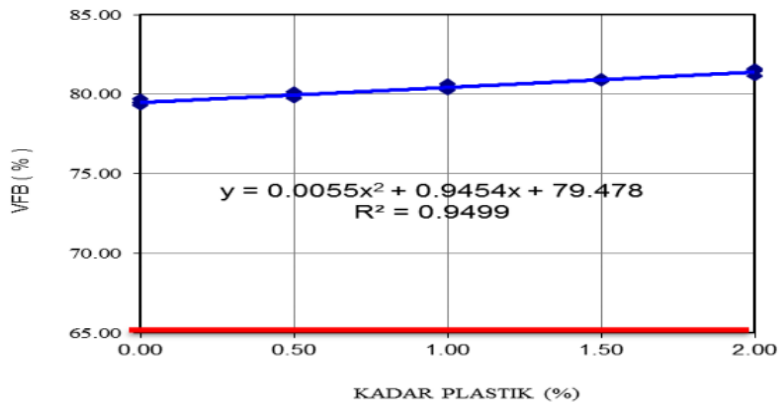

Gambar 8. Hubungan VFB Dengan Kadar Plastik

Dengan menggunakan kadar plastik $0 \%-2 \%$ diperoleh nilai VFB antara 79,48-81,40. Nilai VFB dengan kadar plastik $0 \%, 0,5 \%, 1 \%, 1,5 \%$ dan $2 \%$

Berdasarkan Gambar 8 dapat disimpulkan bahwa semakin besar nilai kadar plastik maka nilai VFB akan semakin besar. Di mana aspal akan mengisi semua rongga yang ada dalam campuran dan dalam agregat.

\section{Penentuan Kadar aspal optimum}

Dari tabel dan grafik Marshall Konvensional dapat ditentukan kadar praktis dalam campuran beton aspal yaitu kadar plastik yang memenuhi semua kriteria atau Karakteristik Marshall dan kadar plastik tersebut adalah rentang kadar $0 \%, 0,5 \%$, $1 \%, 1,5 \%$ dan $2 \%$

Dari lapisan AC-BC tersebut, maka ditentukan kadar plastik yang memiliki nilai stabilitas paling tinggi karena AC-BC merupakan jenis campuran beraspal yang digunakan sebagai lapisan binder atau lapisan penopang yang harus memberikan dukungan yang kuat bagi lapasan di atasnya. Lapisan AC-BC tidak berhubungan langsung dengan cuaca, tetapi perlu memiliki stabilitas untuk 
menahan beban lalu lintas yang disebarkan melalui roda kendaraan. Sehingga, dengan kriteria tersebut maka ditentukan kadar limbah kantong plastik untuk campuran AC-BC yaitu pada kadar plastik $2 \%$.

\section{Indeks Kekuatan Sisa (IKS)}

Salah satu pengujian untuk melihat indeks perendaman (ketahanan terhadap waktu perendaman) atau kekuatan suatu campuran, hasil dari pengujian ini adalah rasio stabilitas. Rasio tersebut membandingkan stabilitas dari benda uji Marshall setelah direndam selama \pm 24 jam pada suhu $\pm 60^{\circ} \mathrm{C}$ terhadap stabilitas benda uji marshall dengan perendaman 30 menit yang biasa disebut indeks perendaman (IP) atau indeks kekuatan sisa (IKS). Untuk nilai indeks perendaman/indeks kekuatan sisa dari campuran, dapat dilihat pada tabel 9.

Tabel 9. Nilai Indeks kekuatan sisa

\begin{tabular}{cccc}
\hline \multirow{2}{*}{$\begin{array}{c}\text { Kadar Plastik } \\
(\%)\end{array}$} & \multicolumn{3}{c}{ Nilai Stabilitas } \\
\cline { 2 - 4 } & Konvensional & Immertion & IKS \\
\hline 2 & 1571,37 & 1534,54 & 97,66 \\
2 & 1559,09 & 1522,26 & 97,64 \\
2 & 1583,64 & 1546,81 & 97,67 \\
\hline Rata-rata & $\mathbf{1 5 7 1 , 3 7}$ & $\mathbf{1 5 3 4 , 5 4}$ & $\mathbf{9 7 , 6 6}$ \\
\hline
\end{tabular}

Marshall Immersion adalah salah satu pengujian untuk melihat durabilitas (ketahanan terhadap beban dan pengaruh suhu ) atau keawetan suatu campuran. Dari hasil pengujian Marshall Immersion diperoleh indeks perendaman sebesar $97,66 \%$ dengan kadar plastik 2,00 \%. Nilai indeks perendaman ini telah memenuhi Spesifikasi Umum Bina Marga 2018. Berdasarkan nilai tersebut dapat disimpulkan bahwa perkerasan jalan yang menggunakan Agregat dari Sungai Jeneberang, Kecamatan Bili-bili, Kabupaten Gowa Provinsi Sulawesi Selatan yang di tambahkan dengan limbah plastik dalam campuran AC-BC dapat memberikan pengaruh yang baik untuk campuran Laston AC-BC, dikarenakan limbah kantong plastik mampu meningkatkan stabilitas pada campuran beraspal serta titik leleh limbah kantong plastik tinggi sehingga campuran beraspal tidak cepat mengalami perubahan bentuk dan limbah plastik membantu campuran lebih kedap terhadap air.

\section{KESIMPULAN}

Berdasarkan hasil penelitian diperoleh kesimpulan sebagai berikut :

1. Hasil pengujian karakteristik agregat yang menggunakan bahan dari Sungai Jeneberang, Kecamatan Bili-bili, Kabupaten Gowa Provinsi Sulawesi Selatan untuk setiap pengujian karakteristik agregat memenuhi setiap pengujian karakteristik sesuai dengan ketentuan dari Spesifikasi Umum Bina Marga 2018.

2. Hasil pengujian karakteristik aspal yang digunakan dalam penelitian ini untuk pembuatan campuran AC-BC adalah aspal minyak penetrasi $60 / 70$ dimana hasil pengujian karakteristiknya memenuhi setiap pengujian karakteristik sesuai dengan ketentuan dari Spesifikasi Umum Bina Marga 2018.

3. Hasil pengujian karakteristik campuran AC-BC yang menggunakan bahan tambah limbah kantong plastik diperoleh nilai stabilitas tertinggi berada pada kadar plastik 2,0\% yaitu 1571.37 kg. Untuk nilai indeks perendaman/indeks kekuatan sisa dari campuran AC-BC diperoleh rata-rata sebesar $97,66 \%$. Nilai indeks perendaman ini telah memenuhi Spesifikasi Umum Bina Marga 2018.

\section{DAFTAR PUSTAKA}

[1] S. Sukirman, 2007, Beton Aspal Campuran Panas, Edisi Kedua. Jakarta: Yayasan Obor Indonesia.

[2] R. Krebs D. dan R. Walker D.,1971, Highway Materials,. Michigan: McGrawHill, Universitas Michigan.

[3] C. Kamba dan R. Rachman, 2018, "Marshall Characteristics Test On Hot Rolled Sheet Base Combine Using Nickel Slag For Half Gap Graded," Int. J. Innov. Sci. Eng. Technol., vol. 5, no. 3, Art. no. 3, 2018.

[3] Direkorat Jenderal Bina Marga, 2018, Spesifikasi Umum Bina Marga 2018 untuk Pekerjaan Konstruksi Jalan dan Jembatan. Jakarta Indonesia: Kementerian Pekerjaan Umum dan Perumahan Rakyat.

[4] H. Hardiyatmo Christady, 2019, Perancangan Perkerasan Jalan dan Penyelidikan Tanah, Edisi 3. Yogyakarta: Gajah Mada University Press.

[5] J. Tandibua, R. Rachman, dan J. Tanijaya, 2020, "Study of Laston BC Durability and Permeability Using Coconut Shell Addition Materials," Bali, Indonesia, 2020, vol. 419, doi: 10.1088/1755-1315/419/1/012101.

[6] S. A. Datu, R. Rachman, dan M. Selintung, 2020, "The Effect of Additional Sugar Palm Fibers on the Durability of Mixed Laston AC-WC," Bali, Indonesia, vol. 419, doi: 10.1088/1755-1315/419/1/012063.

[7] D. N. Bunga, R. Rachman, dan M. Selintung, 2019, "Effect of Collision 
Variation towards the Index Retained Strength of Mixed Asphalt Concrete Wearing Course," Int. J. Sci. Eng. Sci., vol. 3, no. 8, Art. no. 8, doi: 10.5281/zenodo.3408003.

[8] Sumardi, R. Rachman, dan J. Tanijaya, 2019, "Study of the Use Bagasse Ash as a Filler Replacement to Characteristics
Asphalt Concrete," Int. J. Sci. Eng. Sci., vol. 3, no. 8, Art. no. 8, doi: 10.5281/zenodo.3408011.

[9] Y. I. Angga, Elizabeth, dan Alpius, 2019, "Karakteristik Campuran AC-WC dan ACBC Berdasarkan Bahan Tambah Serat ljuk.," Paulus Civ. Eng. J. Ojsukipaulusacid, vol. 1, no. 2, hlm. $1-9$. 